\title{
GEMAS E TÉCNICAS ARTESANAIS: LINHA DE ACESSÓRIOS PRODUZIDA POR PROJETOS DE GERAÇÃO DE TRABALHO E RENDA
}

\author{
Daiane Laís Fontana \\ Universidade da Região de Joinville- UNIVILLE \\ daiane_fontana@hotmail.com \\ Elenir Carmen Morgenstern \\ Universidade da Região de Joinville \\ elenir.m@gmail.com
}

Resumo: O resumo apresenta o desenvolvimento e principais resultados da pesquisa de Iniciação Científica e TCC de Graduação em Design intitulada "Gemas e técnicas artesanais: linha de acessórios produzida por projetos de geração de trabalho e renda", que objetivou projetar uma coleção de bolsas produzidas a partir de refugos de gema e couro (descartadas na Região Sul do Brasil) a serem desenvolvidas por integrantes de um Projeto de Extensão Universitária. O referido projeto investe na capacitação de mulheres da comunidade, com vistas a geração de trabalho e renda, por meio do desenvolvimento de artefatos que integrem saberes artesanais locais e métodos e técnicas pertinentes ao campo do design, como serigrafia, estamparia, projeto de produto e projeto de programação visual, modelagem, costura e empreendedorismo. A pesquisa foi instigada pela experiência de 3 anos da pesquisadora, junto ao referido projeto, quando detectaram-se características quanto à diversidade cultural, entre as integrantes, observando-se que todas possuíam algum conhecimento manual e investiam na produção de artefatos representativos da identidade cultural do grupo produtor. A partir desta percepção, optou-se por atrelar tais saberes manuais a uma proposta de desenvolvimento de coleção de bolsas. Atentando-se também à questão da sustentabilidade, com suporte teórico nos escritos de Salcedo (2014), buscou-se trabalhar com refugos de gema descartados por empresas de minérios do Sul do Brasil (nas cidades de Planalto e Ametista do Sul no estado do Rio Grande do Sul) e de couro, recolhidos em estofarias da cidade de Joinville-SC. A metodologia, para o desenvolvimento projetual, seguiu a seguinte diretriz: definição teórica de conceitos relacionada à pesquisa; efetivação de parcerias para o recebimento dos materiais, aplicação de métodos projetuais do campo design, tendo como base os autores Baxter (1998) e Treptow (2013). O projeto foi direcionado por meio das seguintes etapas: pesquisa de público alvo, pesquisa parâmetro de concorrentes, levantamento de tendência, briefing, conceituação, desenvolvimento de painéis imagéticos, geração de alternativas, matriz de decisão e memorial descritivo. Por fim, houve a confecção dos protótipos por meio de duas oficinas ministradas junto às integrantes, resultando em uma coleção com 
dez bolsas desenvolvidas manualmente a partir de refugos de gema e couro desenvolvidas. A investigação, desenvolvida em 2015, como Iniciação Científica e TCC de Graduação em Design está, no presente ano, desdobrando-se a nível de Mestrado, por meio de investigação que propõe a revisão dos processos de produção dos artefatos desenvolvidos a partir de gema e couro descartados e a estruturação de um plano de negócios com vistas a promoção e comercialização dos artefatos projetados e desenvolvidos em parceria com o Projeto AmaViva.

Palavras-chave: Geração de renda; refugos; bolsas.

\section{REFERÊNCIAS}

BAXTER, Mike. Projeto de produto: Guia prático para o design de novos produtos. 2. Ed. São Paulo: Edgard Blücher, 1998;

SALCEDO, Elena. Moda ética para um futuro sustentável. Tradução: Denis Fracalossi. Barcelona: Editora Gustavo Gili,2014;

TREPTOW, Doris. Inventando moda: planejamento de coleção. 5 ed. São Paulo: Edição da Autora, 2013. 